\title{
Optimal allocation and seismic isolation effect analysis of high-damping rubber bearing for Beam Bridge
}

\author{
Wei-shan Wang ${ }^{1,2, a}$, Yu-min Zhang ${ }^{1,3,{ }^{, *} \text { and Wei-rong Wang }}{ }^{2, c}$ \\ ${ }^{1}$ School of Highways, Chang'an University, Xi'an 710064, China; \\ ${ }^{2} \mathrm{Xi}$ 'an highway research institute, Xi'an 710064, China; \\ ${ }^{3}$ School of Mechanical Engineering, Xi'an ShiYou University, Xi'an 710061 ,China. \\ a634173002@qq.com, bzhangyumincorn@163.com, 'c35813930@qq.com
}

\begin{abstract}
As the seismic isolation technique was widely use in aseismic design of bridges, the high-damping rubber bearing were applied to many bridges in order to reduce the seismic response of bridge. Compare the seismic isolation effect of different model high-damping rubber bearing and laminated rubber bearing, the optimal proposal of bearings has been suggested. Sliding bearings used on side piers caused the earthquake distributed unevenly among piers, as changed to high-damping rubber bearing, the seismic response of bridge have effectively controlled into allowable range.
\end{abstract}

Keywords: Beam Bridge, seismic response, high-damping rubber bearing

\section{Introduction}

Previous experiences of bridge damages in earthquake shown that the damage of medium and small span beam bridges focuses on axial and transverse displacement of beam, unseating of superstructure and shear failure of retractor devices. Most of the damages were caused by failure of support fittings $[1,2]$.

The seismic isolation technique was used in aseismic design of bridges by masses of scientists, in order to reduce the damage of bridge caused by earthquakes [3].Seismic isolation bearing have much more mature and is widely used in engineering as one of the seismic isolation measures[4].

High damping rubber bearings (HDR) have good damping performance, and can absorb the seismic energy effectively, so that the seismic response of structure can be reduce greatly in earthquake [5]. Many scholars have made some research on high damping rubber bearings abroad or native, the study found that the earthquake action of bridge could be reduced by high damping rubber bearings under middle and large earthquakes. The displacement and seismic response of bridge can be effectively control so as to achieve the purpose of shock absorption and isolation [6].

Combined with a project item, the damping and isolation effect of HDR set on standard span continuous girder bridge have been analyzed, and the rational distribution methods of bearings have been discussed.

\section{The establishment of finite element analysis model}

A continuous beam bridge with 4 spans of $50 \mathrm{~m}$ has been analyzed as the background, the prestressed concrete continuous T-beams were applied in the upper structure. The cross section of superstructure was 12.15 meters wide and 2.8 meters high, with C50 concrete. The substructure used hollow thin-walled pier, with C40 concrete.

The finite element analysis model of bridge was built by the large finite element analysis software Midas/civil. Spatial beam element is adopted to simulate girder, cover beam and piers. Pile caps were simulated to be fixed in the foundation. The damping ratio of bridge is 0.05 .

Using the design scheme of HDR for reference, the laminated rubber bearing (LRB) of same bearing capacity have been choose to contrast, in order to analyze the seismic effective of HDR. The bearing models selected for bridge have been list in Tab.1 [7]. 
Tab.1 The primary bearing models of bridge

\begin{tabular}{|c|c|c|c|c|}
\hline Pier position & bearing model of HDR & $\begin{array}{c}\text { Permissible } \\
\text { displacement }\end{array}$ & $\begin{array}{l}\text { bearing model of } \\
\text { laminated rubber bearing }\end{array}$ & $\begin{array}{c}\text { Permissible } \\
\text { displacement }\end{array}$ \\
\hline side pier & LNR(H)-420×520×159 & $150 \mathrm{~mm}$ & GYZF4 500×500×132 & $130 \mathrm{~mm}$ \\
\hline middle pier & HDR(II)-670×620×199 & $292 \mathrm{~mm}$ & GYZ $650 \times 700 \times 171$ & $88.2 \mathrm{~mm}$ \\
\hline
\end{tabular}

The bilinear elastic perfectly-plastic model was been used to simulate laminated rubber bearing, and high damping rubber bearings were simplified to bilinear restoring force mechanical model. The bridge site was in an aseismic region of VI degree fortification. according to report of seismic safety evaluation, the earthquake waves with exceeding probability of $40 \%, 10 \%, 2 \%$ in 100 years were been used to make time history analysis for bridge.

\section{The research results and analysis}

\subsection{Analysis result of different bearings}

The dynamic time history analysis method was applied to analyze the seismic response of bridge. As the seismic response of bridge caused by small and middle earthquakes were less than large earthquake, so the seismic response under earthquake waves with exceeding probability of $2 \%$ were list to be discuss. The seismic analysis results of bridge with laminated rubber bearing have shown in Tab.2.

Tab.2 Seismic analysis results of bridge with LRB

\begin{tabular}{|c|c|c|c|c|c|}
\hline $\begin{array}{c}\text { Earthquake } \\
\text { direction }\end{array}$ & $\begin{array}{c}\text { Number } \\
\text { of piers }\end{array}$ & $\begin{array}{c}\text { Bending moment of } \\
\text { pier bottom / } \\
(\mathrm{kN} \cdot \mathrm{m})\end{array}$ & $\begin{array}{c}\text { Shear force of } \\
\text { pier bottom / kN }\end{array}$ & $\begin{array}{c}\text { Displacement of } \\
\text { pier top / cm }\end{array}$ & $\begin{array}{c}\text { Displacement of } \\
\text { bearings / cm }\end{array}$ \\
\hline \multirow{4}{*}{ axial } & 1 & 346440 & 9667 & 21.05 & 49.44 \\
\cline { 2 - 6 } & 2 & 349078 & 6191 & 47.03 & 23.67 \\
\cline { 2 - 6 } & 3 & 317975 & 4533 & 61.25 & 8.95 \\
\cline { 2 - 6 } & 4 & 332456 & 4780 & 59.52 & 10.71 \\
\hline \multirow{4}{*}{ transverse } & 5 & 340258 & 7679 & 28.89 & 43.67 \\
\cline { 2 - 6 } & 2 & 158107 & 4519 & 5.00 & 19.35 \\
\cline { 2 - 6 } & 3 & 367973 & 6836 & 26.02 & 26.90 \\
\cline { 2 - 6 } & 4 & 472471 & 6210 & 58.04 & 19.78 \\
\cline { 2 - 6 } & 5 & 487730 & 6184 & 55.26 & 19.47 \\
\hline
\end{tabular}

As the data shown in Tab.2, the seismic response of piers have great different with different bearing model. The bearing displacement, bottom bending moment and shear force of side piers were larger than middle piers. The bearings displacement of pier number 1 is $49.44 \mathrm{~cm}$, which is 6 times more than pier number 3 . The top displacement of side pier was smaller than middle piers. The bearings displacement of pier number 1 is $49.44 \mathrm{~cm}$, which is 6 times more than pier number 3 . It is thus clear that sliding rubber bearing on side piers have the seismic isolation function under earthquake. But, the displacement of sliding rubber bearing is exceeds the allowable value.

Change the laminated rubber bearings to be high damping rubber bearings, and take dynamic time history analysis for bridge with large earthquake. The seismic responses of bridges with different bearing model have been compared, as shown in Tab.3. 
Tab.3 Comparison of Seismic analysis results with HDR and LNR

\begin{tabular}{|c|c|c|c|c|c|c|c|c|c|}
\hline $\begin{array}{c}\text { Earthquake } \\
\text { direction }\end{array}$ & $\begin{array}{l}\text { Number } \\
\text { of piers }\end{array}$ & $\begin{array}{c}\text { Bending } \\
\text { moment } \\
\text { of pier } \\
\text { bottom / } \\
(\mathrm{kN} \cdot \mathrm{m})\end{array}$ & $\begin{array}{c}\text { HDR/ } \\
\text { LRB }\end{array}$ & $\begin{array}{c}\text { Shear } \\
\text { force } \\
\text { of pier } \\
\text { bottom } \\
/ \mathrm{kN}\end{array}$ & $\begin{array}{c}\text { HDR/ } \\
\text { LRB }\end{array}$ & $\begin{array}{c}\text { Displacement } \\
\text { of pier top / } \\
\text { cm }\end{array}$ & $\begin{array}{c}\text { HDR/ } \\
\text { LRB }\end{array}$ & $\begin{array}{c}\text { Displacement } \\
\text { of bearings / } \\
\mathrm{cm}\end{array}$ & $\begin{array}{c}\text { HDR/ } \\
\text { LRB }\end{array}$ \\
\hline \multirow{5}{*}{ axial } & 1 & 83664 & 0.24 & 3899 & 0.40 & 5.27 & 0.25 & 47.34 & 0.96 \\
\hline & 2 & 214133 & 0.61 & 5081 & 0.82 & 28.69 & 0.61 & 23.75 & 1.00 \\
\hline & 3 & 190595 & 0.60 & 3534 & 0.78 & 39.47 & 0.64 & 12.67 & 1.42 \\
\hline & 4 & 197690 & 0.59 & 3772 & 0.79 & 37.74 & 0.63 & 14.66 & 1.37 \\
\hline & 5 & 128979 & 0.38 & 3610 & 0.47 & 10.34 & 0.36 & 41.35 & 0.95 \\
\hline \multirow{5}{*}{$\begin{array}{l}\text { transver } \\
\text { se }\end{array}$} & 1 & 126020 & 0.80 & 3385 & 0.75 & 4.20 & 0.84 & 35.58 & 1.84 \\
\hline & 2 & 233871 & 0.64 & 4533 & 0.66 & 16.64 & 0.64 & 24.28 & 0.90 \\
\hline & 3 & 254493 & 0.54 & 3480 & 0.56 & 31.81 & 0.55 & 13.43 & 0.68 \\
\hline & 4 & 271471 & 0.56 & 4210 & 0.68 & 31.39 & 0.57 & 18.25 & 0.94 \\
\hline & 5 & 112071 & 0.31 & 4130 & 0.57 & 5.29 & 0.33 & 49.35 & 1.39 \\
\hline
\end{tabular}

Compare the seismic responses of bridge in Tab.2 and Tab.3, the laws of seismic response with HDR is similar to bridge with LRB under earthquake. The bearing displacement of side piers was almost 4 times larger than middle piers. The bottom bending moment, shear force and top displacement of side piers were relatively less than middle piers, especially the axial top displacement of side piers was almost 1/8 of middle piers. All the response of bridge under earthquake were been controlled with the application of HDR, the bottom bending moment, shear force and top displacement of bridge were about $80 \%$ compared to bridge with LRB.

The function of slide high damping rubber bearings (LNR) is the same as sliding rubber bearing (GYZF4). Both of them have the seismic isolation function for side piers under earthquake, but the force on side and middle piers were significantly different. Meanwhile, the displacement of LNR on side piers were far exceeds its design displacement $150 \mathrm{~mm}$. In order to meet the displacement needs of bearings under earthquake, other specifications of bearings were suggest to trial in order to get a reasonable bearing setting scheme.

\subsection{Optimization selection of HDR}

Base on large amount of trial calculation, the model of HDR (II) $620 \times 670 \times 233$ were been suggest to setting on the bridge so as to get a relatively reasonable seismic response of bridge. The parameters of bearing were list in Tab.4.

Tab.4 The design parameters of suggested bearing

\begin{tabular}{ccccc}
\hline Bearing model & $\begin{array}{c}\text { Yield force/ } \\
\mathrm{kN}\end{array}$ & $\begin{array}{c}\text { Yield } \\
\text { displacement/ } \mathrm{mm}\end{array}$ & $\begin{array}{c}\text { Primary stiffness } \\
\mathrm{K} 1 / \mathrm{kN} / \mathrm{m})\end{array}$ & $\begin{array}{c}\text { Secondary stiffness } \\
\mathrm{K} 2 /(\mathrm{kN} / \mathrm{m})\end{array}$ \\
\hline HDR(II) $620 \times 670 \times 233$ & 207 & 286 & 15870 & 2440 \\
\hline
\end{tabular}

The seismic response of bridge with suggest bearing under large earthquake were list in Tab.5. 
Tab.5 Seismic analysis results of bridge with suggest bearing

\begin{tabular}{cccccc}
\hline $\begin{array}{c}\text { Earthquake } \\
\text { direction }\end{array}$ & $\begin{array}{c}\text { Number } \\
\text { of piers }\end{array}$ & $\begin{array}{c}\text { Bending moment of } \\
\text { pier bottom / }(\mathrm{kN} \cdot \mathrm{m})\end{array}$ & $\begin{array}{c}\text { Shear force of } \\
\text { pier bottom / kN }\end{array}$ & $\begin{array}{c}\text { Displacement of } \\
\text { pier top / cm }\end{array}$ & $\begin{array}{c}\text { Displacement of } \\
\text { bearings / cm }\end{array}$ \\
\hline \multirow{6}{*}{ axial } & 1 & 237811 & 6072 & 14.59 & 32.37 \\
& 2 & 207317 & 3837 & 27.69 & 19.30 \\
& 3 & 211240 & 3226 & 40.11 & 5.18 \\
& 4 & 212261 & 3474 & 37.61 & 7.81 \\
\multirow{6}{*}{ transverse } & 5 & 222465 & 5079 & 19.03 & 26.33 \\
& 1 & 129763 & 3695 & 4.08 & 12.99 \\
& 2 & 255410 & 4302 & 17.87 & 21.33 \\
& 4 & 293856 & 4398 & 36.35 & 15.29 \\
\hline
\end{tabular}

As the seismic response shown in Tab.5, as the slide high damping rubber bearings $(\mathrm{LNR}(\mathrm{H})-420 \times 520 \times 159)$ to be changed to HDR (II) $620 \times 670 \times 233$, the bottom bending moment, shear force and top displacement of side piers has a certain increase, but the bearing displacement of side piers were decrease. By the analysis above, it is concluded that the seismic response of bridge was relatively more reasonable as the high damping rubber bearings were set on side piers. The bottom bending moment and shear force of side piers were closed to middle piers, and the earthquake load was equally separated among the piers. The bearing displacement of side piers were relatively decreased, to be effectively controlled into an allowable range of less than $42.9 \mathrm{~cm}$.

\section{Conclusions}

The seismic response of bridge with high damping rubber bearing were less than bridge with laminated rubber bearing, most could be reduce to $80 \%$ of the response with LRB. All the response of bridge under earthquake were been controlled with the application of HDR, the bottom bending moment, shear force and top displacement of bridge were about $80 \%$ compared to bridge with LRB.

The displacement of slide bearings set on side piers were generally larger than other bearings, even exceed the allowable displacement. Meanwhile, the application of slide bearings making earthquake distribute to side piers much less than middle piers, making the load distribution unbalanced among piers.

As the same high damping rubber bearings were applied to side and middle piers, the bottom bending moment and shear force of pier were relatively approximate, earthquake distributed more balance among piers. In the meantime, the displacement of bearings were obviously been decreased as high damping rubber bearings to be applied to whole bridge, making the seismic response to be effectively controlled into allowable range.

\section{Acknowledgments}

This work was financially supported by Scientific Research Program Funded by Shaanxi Communications Department (Program No.13-21K) and Scientific Research Program Funded by Shaanxi Provincial Education Department (Program No.12JK0900) .

\section{References}

[1] Chen Yan-jiang, Guo Kai-min, Li Yong. Behavior of high damping seismic isolation rubber bearings for bridges. Journal of vibration and shock, 34(2015) 136-148. 
[2] Wang Ke-hai, Sun Yong-hong, Wei Han, et al. Comments on Seismic Strengthening for Structural Engineering in China after Wenchuan Earthquake. Journal of Highway and Transportation Research and Development, 25 (2008) 54-59.

[3] Mahmoud, S., Austrell, PE. \& Jankowski, R. Simulation of the response of base-isolated buildings under earthquake excitations considering soil flexibility. Earthquake Engineering and Engineering Vibration, 11(2012) 359-374.

[4] Spyrakos CC, Koutromanos IA and Maniatakis CA (2009), "Seismic Response of Base-isolated Buildings Including Soil-structure Interaction,” Soil Dynamics and Earthquake Engineering, 29(2009) 658-668.

[5] Zhuang Xuezhen, Shen Chaoyong, Jin Jianmin. Experimental study on mechanical property of high damping rubber bearing for bridge. Earthquake Engineering and Engineering Vibration, 26(2006)208-212.

[6] Yamamoto K, Fujita I and Takewaki, "Instantaneous Earthquake Input Energy and Sensitivity in Base-isolated Building,” the Structural Design of Tall and Special Buildings, 20(2011)631- 648. [7] JT/T 842-2012, High damping seismic isolation rubber bearings for highway bridges [S] 